\title{
Elevated cerebrospinal fluid vasopressin in motor neuron disease
}

\author{
J R SECKL, S L LIGHTMAN, R J GUILOFF \\ From the Departments of Medicine and Neurology, Charing Cross and Westminster Medical School, \\ Westminster Hospital, London, UK
}

SUMMARY CSF vasopressin levels were significantly elevated in eight patients with motor neuron disease $(2.5 \pm 0.4 \mathrm{pmol} / \mathrm{l})$ compared with controls $(0.7 \pm 0.1 \mathrm{pmol} / \mathrm{l})$. CSF oxytocin and plasma vasopressin concentrations were similar in the two groups. This finding may be a primary part of the disease process or an epiphenomenon related to increased autonomic and descending pathway activity secondary to abnormal function and/or loss of anterior horn cells.

There is increasing evidence that the pathological processes in motor neuron disease are not limited exclusively to motor pathways and cells. ${ }^{12}$ Patients with motor neuron disease have reduced concentrations of thyrotropin-releasing hormone in their cerebrospinal fluid (CSF) ${ }^{3}$ and in the ventral horns of the spinal cord. ${ }^{4}$ Two other hypothalamic peptides, vasopressin and oxytocin, have been demonstrated in human CSF and spinal cord by radioimmunoassay ${ }^{5}$ and immunohistochemistry. ${ }^{6}$ The origins and functions of these hormones in extra-hypothalamic regions of the CNS and the CSF are unknown. The classical stimuli to peripheral hormone release do not markedly affect CSF concentrations and neither peptide crosses the blood-brain barrier. ${ }^{7}$ It has been suggested that vasopressin and oxytocin may play a role in motor function. ${ }^{8}$ Both are found in the interneuronal networks close to the anterior horn cells. ${ }^{69}$

We have investigated vasopressin and oxytocin in the CSF in patients with motor neuron disease.

\section{Methods}

Eight successive ambulant patients (aged 52-71 yr, mean 61.0 ; three males:five females) with motor neuron disease were investigated (table). Lumbar puncture was performed

Address for reprint requests: Dr JR Seckl, Medical Unit, Charing Cross and Westminster Medical School, Westminster Hospital, Page Street, London SW1P 2AP, UK

Received 24 April 1986 and in revised form 25 September 1986 Accepted 1 October 1986. as part of the routine clinical investigation; none had had previous lumbar puncture. The controls were 12 patients (aged 40-75 yr, mean 62.6; five males:seven females) undergoing lumbar puncture as part of the investigation of lumbar disc prolapse (3), peripheral neuropathy (2), possible multiple sclerosis (2), isolated cranial nerve palsy (2), acute leukaemia without CNS involvement (1), headache (1) and retinal embolism (1).

After 30 min recumbency, venous blood was drawn and then lumbar puncture performed in the lateral decubitus position. CSF pressure was estimated by direct manometry. CSF was obtained for microscopy and biochemistry and then a small aliquot $(<1 \mathrm{ml})$ taken for peptide assay. Blood was taken on ice, centrifuged at $4^{\circ} \mathrm{C}$, the plasma separated and stored at $-20^{\circ} \mathrm{C}$ prior to peptide assay. CSF was stored at $-20^{\circ} \mathrm{C}$. Plasma was extracted through octadecasilyl silica cartridges (Sep-pak, Waters, Mass.) prior to peptide assay; extraction yield $>90 \%$. CSF was estimated directly in sensitive and specific radioimmunoassays. ${ }^{10}$ Intra-assay coefficient of variation (CV) was $<5 \%$ for vasopressin and oxytocin, interassay CV was $15 \%$ for vasopressin and $10 \%$ for oxytocin. The detection limit was $0.2 \mathrm{pmol} / 1$ for plasma and CSF vasopressin and $1.3 \mathrm{pmol} / 1$ for CSF oxytocin.

Peptide data were not normally distributed and were compared by the Mann-Whitney test. Values are means $\pm S E$.

\section{Results}

CSF vasopressin was significantly higher in the motor neuron disease patients $(2.5 \pm 0.4 \mathrm{pmol} / \mathrm{l})$ than the controls $(0.7 \pm 0.1 \mathrm{pmol} / \mathrm{l}), \mathrm{p}<0.01$ (fig). CSF oxytocin was similar in both motor neuron disease patients $(12.4 \pm 1.6 \mathrm{pmol} / \mathrm{l})$ and controls $(10.6 \pm 2 \cdot 1$ $\mathrm{pmol} / \mathrm{l})$. Plasma vasopressin was also similar in motor 
Table Clinical data of motor neuron disease patients

\begin{tabular}{|c|c|c|c|c|c|c|}
\hline Sex & Age (yr) & MND type & $\begin{array}{l}\text { Duration of } \\
\text { illness }\end{array}$ & $\begin{array}{l}\text { Time to severe } \\
\text { incapacity }\end{array}$ & Major disability & $\begin{array}{l}\text { CSF } \\
\text { protein } \mathrm{g} / \mathrm{l}\end{array}$ \\
\hline $\begin{array}{l}\mathbf{F} \\
\mathbf{M} \\
\mathbf{M} \\
\mathbf{F} \\
\mathbf{F} \\
\mathbf{F} \\
\mathbf{F} \\
\mathbf{M}\end{array}$ & $\begin{array}{l}55 \\
71 \\
64 \\
64 \\
52 \\
68 \\
55 \\
59\end{array}$ & $\begin{array}{l}\text { B } \\
\text { ALS } \\
\text { B } \\
\text { B } \\
\text { B } \\
\text { B } \\
\text { ALS } \\
\text { ALS }\end{array}$ & $\begin{array}{r}27 \\
7 \\
17 \\
34 \\
19 \\
26 \\
10 \\
36\end{array}$ & $\frac{21}{\frac{5}{17}} \frac{24}{12}$ & $\begin{array}{l}\text { Anarthria } \\
\text { Tetraparesis } \\
\text { Dysarthria } \\
\text { Anarthria } \\
\text { Dysarthria } \\
\text { Dysarthria } \\
\text { Dysarthria } \\
\text { Weak hands }\end{array}$ & $\begin{array}{l}- \\
0.67 \\
0.59 \\
0.47 \\
0.40 \\
0.24 \\
0.69 \\
0.52\end{array}$ \\
\hline
\end{tabular}

*All patients had $<3$ cells $/ \mathrm{mm}^{3}$. Times in months.

B, bulbar; ALS, amyotrophic lateral sclerosis.

neuron disease patients $(2 \cdot 1 \pm 0 \cdot 3 \mathrm{pmol} / \mathrm{l})$ and in the controls $(1.6 \pm 0.3 \mathrm{pmol} / \mathrm{l})$. CSF protein was identical in the two groups as was the intracranial pressure $(15.0 \pm 1.3 \mathrm{~cm}$. CSF in motor neuron disease patients, $14.1 \pm 1.3$ in controls). There was no apparent relationship between CSF peptide concentration and motor neuron disease type, duration of illness or time to severe incapacity.

\section{Discussion}

We present evidence that CSF vasopressin is elevated

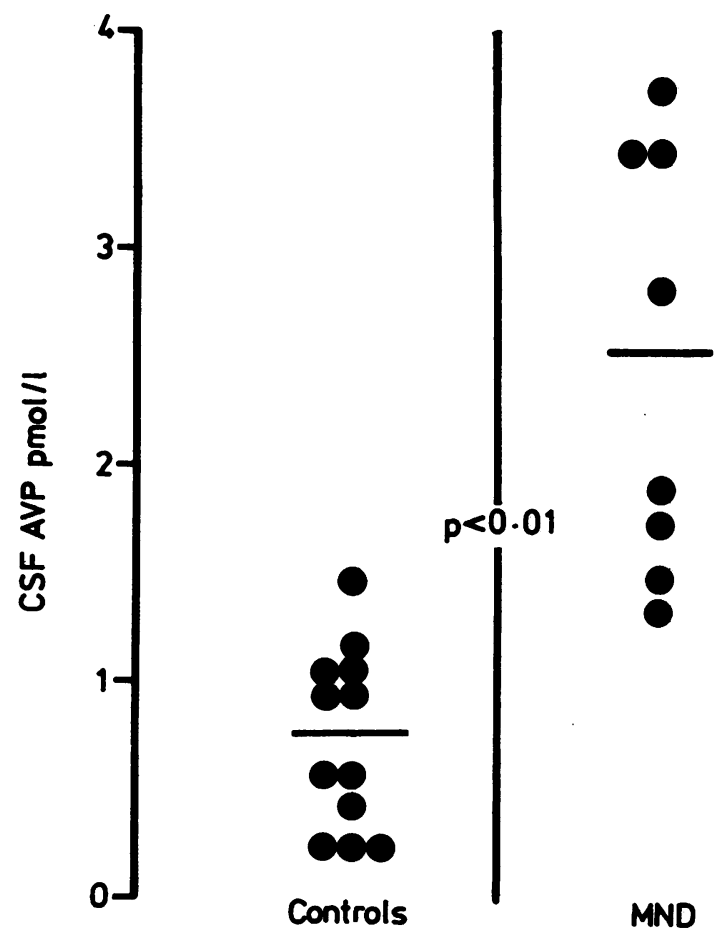

Fig CSF vasopressin (AVP) concentrations in patients with motor neuron disease and controls. Mann-Whitney test. in motor neuron disease. This is not part of a generalised release of neurohypophyseal peptides into CSF in this disease as CSF oxytocin levels are similar to control values. Neither do the CSF vasopressin concentrations reflect changes in plasma levels of this hormone.

CSF vasopressin has been reported to be elevated in conditions associated with raised intracranial pressure. ${ }^{11}$ This did not appear to be a factor in this study.

Vasopressin has been found in fibres in laminae II, $\mathrm{V}$ and VI of the spinal cord and oxytocin in laminae I, III, IV and IX. ${ }^{68}$ Laminae V and VI are closely related to the interneuronal network situated dorsallys to lamina IX, which contains anterior horn cells. ${ }^{\circ} \mathrm{C}$ Thus the elevated CSF vasopressin levels may reflecto increased activity of these neurons, either as a compensatory mechanism secondary to the primaryo pathology or as part of the underlying disease process. Alternatively, there may be loss of peptide secondary to non-specific damage to cells neighbouring the motor neurons, although the selective rise of vasopressin, but not of oxytocin which is more widely distributed, does not support this explanation.

Although patients with motor neuron disease do not usually describe symptoms of autonomic dysfunction, there is evidence of an impaired response to head-up tilt and increased sensitivity to infused noradrenalin, thought to involve central mechanisms. ${ }^{12}$ The evidence of autonomic dysfunction has been supported by recent pathological findings. ${ }^{1}$ There is increasing evidence for a role for vasopressin in the central control of autonomic function. ${ }^{1314}$ The elevated CSF vasopressin levels in motor neuron disease may be associated with these changes.

JRS was supported by a Sir Jules Thorn Charitable Trust Research Fellowship.

\section{References}

1 Kennedy PGE, Duchen LW. A quantitative study of intermediolateral column cells in motor neurone disease and the Shy-Drager syndrome. J Neurol 
Neurosurg Psychiatry 1985;48:1103-6.

2 Matheson JK, Harrington HJ, Hallett M. Abnormalities of multimodality evoked potentials in amyotrophic lateral sclerosis. Arch Neurol 1986;43:338-40.

3 Engel WK, Siddique T, Nicoloff JT, Wilber JF. TRH levels are reduced in CSF of amotrophic lateral sclerosis (ALS) and other spastic patients, and rise with intravenous treatment. Neurology 1983;33(suppl 2): 176.

4 Mitsuma T, Nogimori T, Adachi K, Mokoyama M, Ando $K$. Concentrations of immunoreactive thyrotropin-releasing hormone in spinal cord of patients with amyotropic lateral sclerosis. Am J Med Sci 1984;287:34-6.

5 Jenkins JS, Ang VTY, Hawthorn J, Rossor MN, Iversen LL. Vasopressin, oxytocin and neurophysins in the human brain and spinal cord. Brain Res 1984; 291:111-7.

6 Sofroniew MV. Projections from vasopressin, oxytocin and neurophysin neurones to neural targets in the rat and human. J Histochem Cytochem 1980;28:475-8.

7 Robinson ICAF. Neurohypophyseal peptides in cerebrospinal fluid. In: Cross BA, Leng G, eds. The Neurohypophysis; Structure, Function and Control, Progress in Brain Research, Vol 60. Amsterdam 1983:129-45.
8 Delwaide PJ, Schoenen J, Burton L. Central actions of neurotropic drugs assessed by reflex studies in man. In: Desmedt JE, ed. Motor control mechanisms in health and disease. Adv Neurology 1983;39:977-96.

9 Szentagothai J, Rethelyi J. Cyto- and neuropil architecture of the spinal cord. In: Desmedt JE, ed. New Developments in Electromyography and Clinical Neurophysiology. Vol 3. Basel: Karger, 1973:20-7.

10 Williams TDM, Carter DA, Lightman SL. Sexual dimorphism in the posterior pituitary response to stress in the rat. Endocrinology 1985;116:738-40.

11 Sorensen PS, Gjerris F, Hammer M. Cerebrospinal fluid vasopressin and increased intracranial pressure. Ann Neurol 1984;15:435-40.

12 Steiner TJ, Sethi KD, Rose FC. Autonomic function in motor neurone disease. In: Rose FC, ed. Research Progress in Motor Neurone Disease. London: Pitman, 1984:180-8.

13 Schmid PG, Sharabi FM, Guo GB, Abboud FM, Thames MD. Vasopressin and oxytocin in the neural control of the circulation. Fed Proc 1984;43:97-102.

14 Carter DA, Lightman SL, Vallejo M. Vasopressin modifies the cardiovascular response to noradrenalin microinjection in the nucleus of the tractus solitarius in rats. J Physiol (Lond) 1985;360:55P. 